\title{
Ecological weed control in rice and maize using Orbygnia phalerata with focus on the weed seedbank in the soil
}

\author{
Mário Luiz Ribeiro Mesquita*1, Leonaldo Alves de Andrade ${ }^{2}$, Walter Esfrain Pereira ${ }^{2}$ \\ ${ }^{1}$ Universidade Estadual do Maranhão, Programa de Pós-Graduação em Agricultura e Ambiente, CEP 65.055-098, São \\ Luís, Maranhão, Brasil \\ ${ }^{2}$ Universidade Federal da Paraíba/ Campus Areia, Centro de Ciências Agrárias, Programa de Pós-Graduação em \\ Agronomia, Brasil
}

*Corresponding author: mario-mesquita51@hotmail.com

\begin{abstract}
The aim of this study was to evaluate the effect of mulching with dry leaves of babassu palm (Orbygnia phalerata Mart.) on germination of weed seed bank on rice tiller number and on grain yield of rice and maize in Maranhão state, northeastern Brazil. In the field the experimental design was a split plot in a randomized complete block with 15 replications. Rice, maize and rice intercropped with maize were allocated to the main plots and mulching treatments with unprocessed whole dried palm leaves $(0$ and $23 \mathrm{t} \mathrm{ha}^{-1}$ ) to the subplots. Germination of the weed seed bank was assessed after crop harvest in the greenhouse by means of a collection of three soil samples per subplot $(n=270)$ with an open metal device of $25 \mathrm{~cm}$ in length $\times 16 \mathrm{~cm}$ in width $\times 3 \mathrm{~cm}$ in height as sampling unit. Soil samples were placed in aluminum trays in the greenhouse and irrigated daily. The germinated weed species were identified and counted every fifteen days. The results showed that mulching can reduce germination in the weed seed bank up to $55 \%$ and promoted a significant increase in rice tiller number from 63 to $95 \mathrm{~m}^{-2}$, grain yield of rice from 1,077 to $2,251 \mathrm{~kg}$ ha ${ }^{-1}$ and grain yield of maize from 1,137 to $2,293 \mathrm{~kg} \mathrm{ha}^{-1}$. Therefore, mulching can be recommended for weed control in smallholder farming of rice and maize crops.
\end{abstract}

Keywords: Allelopathy; Biological Invasion; Competition; Floristic. Abbreviations: APG_Angiosperm Phylogeny Group.

\section{Introduction}

Weeds are a major biological constraint in smallholder farming. They interfere with crop growth and development by allelopathy and competition for water, nutrients, light and space. Uncontrolled weed growth can reduce grain yields by $68 \%$ in maize (Murungu et al., 2018), and by $96 \%$ in rice (Chauhan and Johnson, 2011a, b). Adoption of ecological control methods reduce seedling of weed species from the soil seedbank. Alteration in competitive relations for the benefit of the crop and gradual reduction in the weed seed bank size may contribute to regulate weed populations and reduce the negative impact of weeds on crop production (Chauhan and Johnson, 2011 a, b). Considering that the greatest component weeds present in any agricultural field comes from seeds previously deposited in the soil, the definition of strategies that prevent weed seed germination is of fundamental importance for weed control (Rao et al., 2017).

The soil seed bank is a dynamic system with inputs and outputs. The entrances occur through seed rain, as a result of efficient mechanisms of dispersion, and the exits, through germination, predation and deterioration or death of the seeds. These factors determine the amount of viable seeds present in the soil (Garwood, 1989). The diversity of species may vary depending on the management practices (Ikeda et al., 2008; Ricci et al., 2008). In smallholder farming in the state of Maranhão, northeastern Brazil, there is an enormous lack of knowledge about weed management techniques that consider soil conservation, reduction in slash and burn practice to prepare the land, promotion of nutrient recycling and other techniques that help to recover and maintain environmental sustainability. In this region the system of agricultural exploitation prevails the slash and burn of vegetation, particularly the dry leaves that fall down from babassu palm trees. Therefore, leaves of babassu palm trees are zero-cost, easily accessible material in smallholder farmer communities. Instead of usual burning of leaves they can be used as dead mulching to control weeds in agricultural fields. According to Ranaivoson et al. (2018), the use of mulch reduces the weed germination up to $80 \%$. According to these authors, this occurs because the soil cover blocks the incidence of light on the soil surface and acts as a direct physical impediment in the germination and emergence of many weed species. The effect of using mulch as a strategy for weed management in rice and maize was carried out by several authors (Moraes et al., 2009; Moura et al., 2009; Bunna et al., 2011; Chauhan and Abugho, 2013; 
Kumar et al., 2013; Nuemsi et al., 2018; Ranaivoson et al., 2018). However, none of the authors evaluated the effect of mulching on the germination of the soil seed bank and there are no reports on application of babassu palm leaves, which is a dominant autochthonous species in the secondary vegetation in the agricultural fields of the state of Maranhão, in weed management programs.

In this context, mulching made from dried babassu leaves can reduce weed populations in smallholder cropping fields and, consequently, reduce fires and costs in a sustainable way.

The objective of this research was to evaluate the effect of mulching made from dried leaves of babassu palm on the germination of the weed seedbank in the soil, number of rice tillers and grain yield of rice and maize monocrop and intercropped in smallholder farming the state of Maranhão, northeastern Brazil.

\section{Results and Discussion}

\section{Effect of mulching on germination of the weed seedbank in} the soil

Mulch reduced weed seed germination in the soil seed bank in all treatments with a significant effect on the rice crop ( $P$ $<0.05)$, where there was a reduction of $55 \%$ in weed germination density (Table 1).

As the evaluation time increased, seed germination density in the mulch treatment decreased, showing a quadratic response in the rice crop area (Figure 1).

The reduction of weed seed germination in the soil was occurred because the mulch probably prevented the penetration of light in the soil or blocked certain wavelengths of the light spectrum that are necessary for seed germination of many weed species (Batlla and BenechArnold, 2014). In addition, the physical barrier formed by straw may have contributed to the mortality of germinated seedlings of seeds located on the soil surface, whose reserves were not sufficient to overcome the mulch (Gomes and Christoffoleti, 2008; Gardarin et al., 2010).

Similar results have been reported for rice and maize crops elsewhere in the tropical region. For example in India, Singh et al. (2007), evaluated wheat (Triticum aestivum L.) straw as mulch and observed a $54 \%$ reduction in the weed density at 30 days after rice planting. In the Amazon region, Moura et al. (2009), observed that the cut of the legumes Acacia mangium Willd. and Leucaena leucocephala (Lam.) De Wit, used as mulching, resulted in $89 \%$ decrease in the weed biomass in the maize crop after five years of an alley cropping study. In the state of Rio Grande Sul, southern Brazil, Moraes et al., (2009) reported that mulching with dry parts of Azevém (Lolium multiflorum L.) resulted in an increase of $80.72 \%$ in maize grain yield.

In total, we sampled 28,499 individuals from 23 families, 49 genera and 71 species in the weed seedbank in the soil (Supplementary Table 1).

The families Cyperaceae and Poaceae had the largest number of species, with 11 each, followed by Malvaceae, with eight; Asteraceae, with seven, Amaranthaceae, with six; Fabaceae and Rubiaceae, with four; Phyllanthaceae, with three; Onagraceae, Lamiaceae, Commelinaceae and Convolvulaceae with two and the others with one species each. The genera that stood out most were Sida, with six species, Cyperus with five, Amaranthus with four, and Phyllanthus, Fimbristylis and Digitaria, with three species each.

The mulching treatment changed the floristic composition of the soil seed bank, with the disappearance of species of the families Lamiaceae, Loganiaceae and Nyctaginaceae of the area planted with rice, Lamiaceae and Turneraceae of the maize area; and Turneraceae, Brassicaceae and Lamiaceae from the rice intercropped with maize.

In the rice area, based on the record of occurrence of soil seed bank germination, mulching was effective in controlling the species Amaranthus retroflexus, Eclipta alba, Mimosa pudica, Hyptis suaveolens, Spigelia anthelmia, Sida urens, Boerhavia erecta, Ludwigia leptocarpa, Phyllanthus corcovadensis, Phylllanthus orbicularis Digitaria horizontalis and Urtica dioica. The blocking of light penetration on the soil surface seems to have been the main mechanism responsible for this result, since some of these species produce seeds that are positive photoblastic; thus, they need light to germinate such as those in Eclipta alba (Chauhan and Johnson, 2008), Hyptis suaveolens (Mandal et al., 2008), Digitaria horizontalis (Mondo et al., 2010)) and Urtica dioica (Jankowska-Blaszczuk and Daws, 2007).

In maize, the species Ageratum conyzoides, Commelina diffusa, Fimbristylis autumnalis, Schoenoplectus juncoides, Scleria lithosperma, Calopogonium mucunoides, Mimosa pudica, Urena lobata, Richardia brasiliensis and Turnera subulata were eliminated by mulching. Among these species, two also produce positive photoblastic seeds, Ageratum conyzoides (Caton et al., 2010; Sun et al., 2012) and Fimbristylis autumnalis (Caton et al., 2010).

In the rice intercropped with maize, mulching was effective in controlling the species Cleome affinis, Ipomoea ramosissima, Cyperus aggregatus, Cyperus meyenianus, Desmodium adscendens, Hyptis suaveolens, Sida glaziovii, Phyllanthus corcovadensis, and Turnera subulata. Among these, Cyperus aggregatus only germinates in the presence of light (Mclvor and Reid, 2011).

\section{Effect of mulching on rice tiller number and grain yield of rice and grain yield of maize}

The mulching treatment had a significant effect $(P<0.05)$ on the increase in the number of rice tillers and grain yield of rice and maize. In the rice crop, there was an increase of $50.7 \%$ in the number of tillers and $109 \%$ in the grain yield. In the maize crop, there was a grain yield increase by $101 \%$ (Table 2). This was due to the decrease in competition for nutrients, space, water and light which altered competitive relations in favor of the crops.

The hypothesis of this research is that mulching, made from low cost material and easy access in the farmer communities, can reduce the germination of the weed seedbank in the soil, constituting a management strategy for weed control in smallholder farming in the state of Maranhão, besides providing other benefits to the soil. This is because mulching prevents light from penetrating the soil surface or blocks certain wavelengths of light spectrum that are required for the seed germination of most weed species. In addition, it forms a physical barrier that prevents germination and/or emergence of many weed species. 
Table 1. Germination density in the weed seedbank in the soil grown with rice and maize monocrop and intercropped with and without mulching in the state of Maranhão, northeastern Brazil.

\begin{tabular}{lccc}
\hline \multirow{2}{*}{ Treatments } & & \multicolumn{2}{c}{ Weed seed germination density $\left(\right.$ plants $\mathrm{m}^{-2}$ ) } \\
\cline { 2 - 4 } & Rice & Maize & Rice intercropped with maize \\
Without mulching & $6113 \mathrm{a}$ & $2466 \mathrm{a}$ & $2330 \mathrm{a}$ \\
With mulching & $2781 \mathrm{~b}$ & $1131 \mathrm{a}$ & $1012 \mathrm{a}$ \\
\hline Means followed by the same letter in the column do not differ by the Tukey test at 5\% probability
\end{tabular}

Means followed by the same letter in the column do not differ by the Tukey test at $5 \%$ probability.

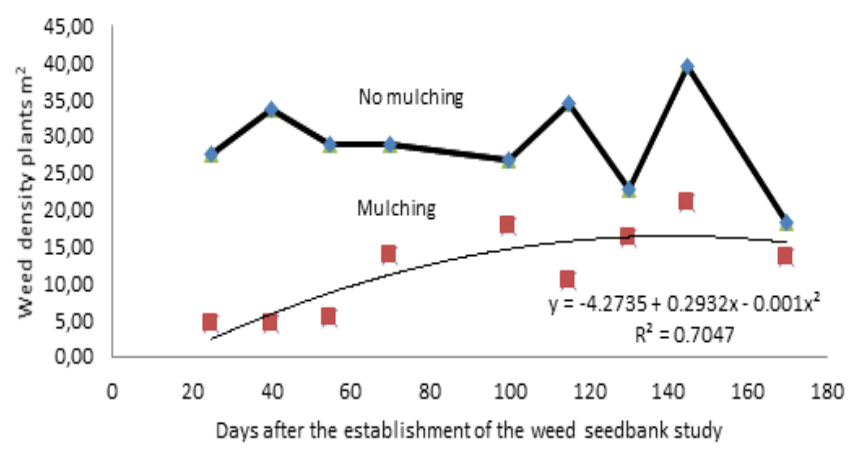

Fig 1. Weed germination density in the weed seedbank in the soil in a rice field without and with mulching made with unprocessed whole dried leaves of babassu palm in the state of Maranhão, northeastern Brazil according to the time (days) of evaluation.

Table 2. Number of rice tillers and grain yield of rice and maize with and without mulching in the state of Maranhão, northeastern Brazil.

\begin{tabular}{llll}
\hline \multirow{2}{*}{ Treatments } & \multicolumn{2}{c}{ Rice } & Maize \\
\cline { 2 - 4 } & $\begin{array}{l}\text { Tillers } \\
\left(\mathrm{n} \mathrm{m} \mathrm{m}^{-2}\right)\end{array}$ & $\begin{array}{l}\text { Grain yield } \\
\left(\mathrm{kg} \mathrm{ha}^{-1}\right)\end{array}$ & $\begin{array}{l}\text { Grain yield } \\
\left(\mathrm{kg} \mathrm{ha}^{-1}\right)\end{array}$ \\
\hline Without mulching & $63 \mathrm{~b}$ & $1077 \mathrm{~b}$ & $1137 \mathrm{~b}$ \\
With mulching & $95 \mathrm{a}$ & $2251 \mathrm{a}$ & $2293 \mathrm{a}$ \\
\hline
\end{tabular}

Means followed by the same letter in the column do not differ by the Tukey test at $5 \%$ probability.

In fact, in the experiment using 23 tons ha $^{-1}$ of unprocessed whole dried leaves of the babassu palm placed on the soil, we verified a reduction of $55 \%$ in the germination density of the weed soil seed bank in the soil of areas grown with rice and maize monocrop and intercropped in the state of Maranhão (Table 2), confirming the hypothesis proposed. The reduction in the weed seed germination altered the competitive relations in favor of the crops resulting in an increase in the rice tiller number and the grain yield of rice and maize (Table 4), which corroborates the hypothesis.

Other works described in the literature confirm that the proposed hypothesis is also applicable to the use of mulch with other materials. In fact, rice straw (Murungu et al., 2011; Chauhan and Abugho, 2013), wheat residue mulch (Kumar et al., 2013), Stylosanthes guianensis and a mixture of maize and Dolichos lablab (Ranaivoson et al., 2018) and dead vegetation cover (Nuemsi et al., 2018) showed a similar response in the weed control in rice and maize.

Throughout the discussion, mulching with babassu palm dry leaves can be used as a strategy to weed control in areas of smallholder farming in the state of Maranhão.

\section{Materials and Methods}

\section{Study site}

This research was carried out in the villages of Boa

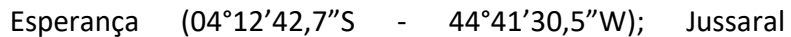
$\left(04^{\circ} 06^{\prime} 03,4^{\prime \prime} \mathrm{S}-44^{\circ} 56^{\prime} 42,9^{\prime \prime} \mathrm{W}\right)$ and Encruzilhada $\left(04^{\circ} 23^{\prime} 34,8^{\prime \prime} \mathrm{S}-44^{\circ} 37^{\prime} 19,8^{\prime \prime} \mathrm{W}\right)$ located, respectively in the municipalities of Bacabal, Lago Verde and São Luís Gonzaga, in the state of Maranhão, northeastern Brazil.

The climate of the region is Aw, according to Köppen's classification, which is tropical hot and humid, with a rainy season from January to June and a dry season, from July to December. The average temperature is $25{ }^{\circ} \mathrm{C}$ and rainfall is around $1,800 \mathrm{~mm}$ annually (NUGEO, 2015). Soils of the study sites are classified as Plintosols with clay texture and vegetation is classified as open ombrophylous forest with Babaçu (Orbignya phalerata Mart.) Arecaceae, secondary forest fallow regrowth which had suffered frequent previous slash-and-burn agriculture cycles. (Gehring et al., 2011).

\section{Experimental design}

The experiments were stablished in a randomized complete block design with three treatments and 15 replications, in a split plot arrangement. The treatments were rice, maize and rice intercropped with maize allocated to the plots and the mulch ( 0 and $23 \mathrm{t} \mathrm{ha}^{-1}$ of dried babassu leaves) in the subplots. The experimental area was composed of 45 plots of $5.0 \mathrm{~m} \times 10.0 \mathrm{~m}$ divided in 90 subplots of $5.0 \mathrm{~m} \times 5.0 \mathrm{~m}$. The useful area of each subplot was established in $4.0 \mathrm{~m} \times$ $4.0 \mathrm{~m}$. Mulching was done before planting in the end of December 2008, with two unprocessed whole dried leaves of the Babassu palm tree (Orbygnia phalerata Mart.) on top of one another so that the soil was completely covered with the placement of two dried leaves of the Babaçu palm tree 
(Orbygnia phalerata Mart.) on top of one another so that the soil was completely covered.

\section{Plant materials}

Land preparation for planting was done manually at the end of the dry season in November 2008. There was no soil plowing and no corrective and fertilizer applications.

Rice and maize were planted in pits at the beginning of the rainy season in January 2009 with manual planters that opened space in the straw sufficient for planting and seed germination.

The varieties of rice and maize were Bonança and BR - 106, respectively, which are planted regularly by farmers in the region.

For monocrop rice, it was planted in pits with a spacing of $0.40 \mathrm{~m} \times 0.40 \mathrm{~m}$ with the consumption of $50 \mathrm{~kg}$ of seeds ha ${ }^{-1}$. Maize was planted in rows with spacing of $1.0 \mathrm{~m} \times 0.20 \mathrm{~m}$ with $20 \mathrm{~kg}$ of seeds ha ${ }^{-1}$. In rice-maize intercropping, rice was planted in pits with the same spacing and seed consumption as in monocrop and maize was planted in rows with a spacing of $3.0 \mathrm{~m} \times 0.10 \mathrm{~m}$ with a consumption of $7 \mathrm{~kg}$ of seeds $\mathrm{ha}^{-1}$.

The manually harvested rice panicles and maize ears were sun dried and were manually threshed and the grains were weighed.

\section{Assessment of rice and maize variables}

The crop variables assessed were the number of tillers $\mathrm{m}^{-2}$ at 30 days after emergence for rice and grain yield for both rice and maize expressed as $\mathrm{kg}$ grains $\mathrm{ha}^{-1}$ corrected to $13 \%$ moisture.

\section{Assessment of the weed seedbank traits}

The effect of mulching on the weed seedbank germination was assessed ex situ right after crop harvest. For this, three soil samples were collected per subplot in July 2009 with an open metal rectangle with $25 \mathrm{~cm}$ in length $16 \mathrm{~cm}$ in width and $3 \mathrm{~cm}$ in depth. The rectangle was introduced into the soil. All the material delimited by the internal perimeter was removed.

The samples were placed in black plastic bags, labeled and transported to the School Farm of the Agrarian Sciences Center of the Maranhão State University in São Luis, where they were transferred to a greenhouse protected with $50 \%$ shading. Thereafter the soil samples were placed in aluminum trays of $25 \mathrm{~cm}$ in length, $16 \mathrm{~cm}$ in width and $5 \mathrm{~cm}$ in depth in July 2009. The trays were perforated to facilitate drainage and irrigated daily.

Three trays with washed sand were added to a batch of 90 samples to serve as test control. This was done due to the possibility of seed rain contamination of seeds from local weeds. No contamination was observed during the conduction time of the experiment.

The identification, counting and removal of the germinated species from the trays was done every fifteen days, during a period of 130 days, from August 2009 to February 2010. At 60 days, the irrigation was suspended for two weeks and the soil was revolved with the purpose of facilitating the germination of the seeds located in the lower part of the trays. Seven evaluations were made, four before and three after water stress.

The botanical identification of the species was made by analyzing the external morphology of the vegetative and reproductive parts and the specialized bibliography, by comparison with other species already identified and also by consulting specialists. The species that could not be immediately identified were transplanted into plastic containers and cultivated until they reached the flowering period. The Angiosperm Phylogeny Group IV classification system was used (APG IV, 2016).

\section{Statistical analyses}

The weed germination density, the number of rice tillers and the grain yields of rice and maize were analyzed by Analysis of Variance. The means were compared by the Tukey test. Regression analysis was also performed according to the days after seed bank implantation. All analyzes were performed using the SAS / STAT program (SAS, 2011).

\section{Conclusion}

The use of mulch with unprocessed whole dried leaves of the babassu palm in one growing season reduced the germination of the weed seed bank by $55 \%$ in rice and maize grown in monocrop or in intercropping. Soil mulching with unprocessed whole dried of the babassu palm promotes a significant increase in the number of rice tillers and grain yield of rice and grain yield of maize.

\section{Acknowledgments}

The authors thank CAPES (Coordenação de Aperfeiçoamento de Pessoal de Nível Superior) for financial support.

\section{References}

APG - Angiosperm Phylogeny Group IV (2016) An update of the Angiosperm Phylogeny Group classification for the orders and families of flowering plants. Bot J Linn Soc. 181:1-20.

Battla D, Benech-Arnold RL (2014) Weed seed germination and the light environment: Implications for weed management. Weed Biol Manag. 14(2):77-87.

Bunna S, Sinath, P, Makara O, Mitchel J, Fukai S (2011) Effects of straw mulch on mungbean yield in rice fields with strongly compacted soils. Field Crop Res. 124:295301.

Caton BP, Mortimer M, Hill JE, Johnson DE (2010) A practical field guide to weeds of rice in Asia. Second Edition. Los Baños (Philippines): International Rice Research Institute, 2010. 118p.

Chauhan BS, Johnson DE (2008) Influence of environmental factors on seed germination and seedling emergence of Eclipta (Eclipta prostata) in a tropical environment. Weed Sci. 56:383-388.

Chauhan BS, Johnson DE (2011a) Row spacing and weed control timing affect yield of aerobic rice. Field Crop Res. 121:226-231. 
Chauhan B, Johnson DE (2011b) Ecological studies on Echinochloa crus-galli and the implications for weed management in direct-seeded rice. Crop Prot. 30(11): 13851391.

Chauhan BS, Abugho SB (2013) Effect of crop residue on seedling emergence and growth of selected weed species in a sprinkler-irrigated zero-till dry-seeded rice system. Weed Sci. 61:403-409.

Gardarin A, Dürr C, Colbach N (2010) Effects of seed depth and soil aggregates on the emergence of weeds with contrasting seed traits. Weed Res. 50:91-101.

Garwood NC (1989) Tropical soil seed banks: a review. In: Leck MA, Parker VT, Simpson RL (ed.) (1989) Ecology of soil seed banks, Academic Press, San Diego. 9.

Gehring C, Zelarayán MLC, Almeida RB, Moraes FHR (2011) Allometry of the babassu palm growing on a slash-andburn agroecosystem of the eastern periphery of Amazonia. Acta Amazon. 41(1):127 - 134.

Gomes Jr FG, Christoffoleti PJ (2008) Biologia e manejo de plantas daninhas em áreas de plantio direto. Planta Daninha. 26:789-798.

Ikeda FS, Mitja D, Vilela L, Silva JCS (2008) Banco de sementes em cerrado sensu stricto sob queimada e sistemas de cultivo. Pesqui Agropecu Bras. 43:667-673.

Jankowska-Blaszczuk M, Daws MI (2007) Impact of red : far red ratios on germination of temperate forest herbs in relation to shade tolerance, seed mass and persistence in the soil. Funct Ecol. 2:1055-1062.

Kumar V, Singh S, Chhokar RS, Malik RK, Brainard DC, Ladha JK (2013) Weed management strategies to reduce herbicide use in zero-till rice-wheat cropping systems of the indo-gangetic plains. Weed Technol. 27:241-254.

Mandal SM, Chakraborty D, Gupta K (2008) Seed size variation: influence on germination and subsequent seedling performance in Hyptis suaveolens (Lamiaceae). Res J Seed Sci. 1(1): 26-33.

Mclvor JG, Reid DJ (2011) Germination characteristics of tropical and subtropical rangeland species. Rangeland J. 33(2):195-208.

Mondo VHV, Carvalho SJP, Dias ACR, Marcos Filho J (2010) Efeitos da luz e temperatura na germinação de sementes de quatro espécies de plantas daninhas do gênero Digitaria. Rev Bras Sem. 32(1):131-137.
Moraes PVD, Agostineto D, Vignolo GK, Santos LS, Panozzo LE (2009) Manejo de plantas de cobertura no controle de plantas daninhas na cultura do milho. Planta Daninha. 27:289-296.

Moura EG, Aguiar AF, Ferraz Junior, ASL, Costa MG, Silva Junior EM, Gehring C (2009) Incidência de ervas daninhas e atributos do solo em um agrossistema da pré-amazonia, sob efeito da cobertura morta de diferentes combinações de leguminosas em aléias. Sci Agrar. 10:007-014.

Murungu FS, Chiduza C, Muchaonyerwa, P, Mnkeni PNS (2011) Mulch effects on soil moisture and nitrogen, weed growth and irrigated maize productivity in a warmtemperate climate of South Africa. Soil Till Res. 112:58-65

Nuemsi PPK, Tonfack LB, Taboula JM, Mir BA, Mbanga MRB, Ntsefong GN, Temegne CN, Youmbi E (2018) Cultivation systems using vegetation cover improves sustainable production and nutritional quality of new rice for Africa in the tropics, Rice Sci. 25(5): 286-292

Ranaivoson L, Naudin K, Ripoche A, Rabeharisoa L,_Corbeels M (2018) Is mulching an efficient way to control weeds? Effects of type and amount of crop residue in rainfed rice based cropping systems in Madagascar. Field Crop Res. 217:20-31.

Rao AN, Brainard DC, Kumar V, Ladha JK, Johnson DE (2017) Preventive weed management in direct-seeded rice: targeting the weed seedbank. In: Donald L. Sparks DL (ed) Advances in Agronomy, Vol. 144, Burlington: Academic Press, pp. 45-142. 4

Ricci MSF, Virgínio Filho EM, Costa JR (2008) Diversidade da comunidade de plantas invasoras em sistemas agroflorestais com café em Turrialba, Costa Rica. Pesqui Agropecu Bras. 43:825-834.

SAS - Statistical Analysis System. (2011) User's guide: statistics. Version 8.0. Cary, SAS Institute, (CD-ROM).

Silva, PSLS, Silva, ES, Mesquita, SSX (2004) Weed control and green ear yield in maize. Planta Daninha. 22(1):137-144.

Singh S, Ladha JK, Gupta RK, Bhushan L, Rao, AN, Sivaprasad B, Singh PP (2007) Evaluation of mulching, intercropping with Sesbania and herbicide use for weed management in dry-seeded rice (Oryza sativa L.). Crop Prot. 26:518-524.

Sun P, Mantri N, Möller M, Shen J, Shen Z, Jiang B, Chen C, Miao Q, Lu H (2012) Influence of light and salt on the growth of alien invasive tropical weed Ageratum conyzoides. Aust J Crop Sci. 6:739-748. 